\title{
Reengineering Model for the Education System to Improve the Academic Achievement of Students in Jordanian Schools
}

\author{
Dr. Azhar Khader Dagher
}

\begin{abstract}
The study aimed to develop a reengineering model of the education system to improve the academic achievement of students in Jordanian schools, by knowing the reality of achievement of students in Jordanian schools, from the point of view of teachers and principals. The study sample consisted of (783) teachers and principals for the academic year (2018/2019). To analyze the study data, the mathematical averages, standard deviations, and (t-test) were used. The study showed that the reality of academic achievement among the students in the Jordanian schools came (medium). And showed that there were statistically significant differences in the achievement of students in Jordanian schools, due to the variable (type of job), and in favor of (Teachers). The study also developed a model of system reengineering to improve students' achievement in Jordanian schools.
\end{abstract}

Keywords: Model, Reengineering, Academic Achievement, Jordanian Schools.

DOI: $10.7176 / \mathrm{JEP} / 11-21-15$

Publication date:July 31 st 2020

\section{Introduction:}

Since the beginning of the twenty-first century, the world has witnessed a huge knowledge shift, which has included various aspects of life and its fields, there are new data that appear constantly needing new experiences, skills and new ideas to deal with them successfully, and these transformations have casted a shadow on the structure of the educational system, so there is a need for unconventional education Therefore, preparing a person who is able to cope with all these changes requires reconsidering educational systems concept, content and style, on new bases based on studied scientific strategies that accommodate the available material and human capabilities, accordingly countries began to race Various efforts to develop their educational systems in a comprehensive manner.

Today, the human element (students) as one of the educational outcomes is considered among the most prominent concerns of organizations, whether governmental or private, and its success requirements are the skills they possess, because it is a way to enhance performance and a way to master work. Since mankind lives today in a world of speed, it has become necessary for schools to develop themselves by providing their students with the skills necessary for them, and this can only be achieved by working to develop students level of education and applied skills, so that they can keep pace with everything new as required (Abdel Aziz 2012).

The wealth of any society is not measured by the extent of its natural and material resources only, but also to human resources, because the human element is the basis of the renaissance and material development of societies. Therefore, the success of economical, social, political, environmental and technological development policies that deal with positive and negative impacts of engine changes, such as poverty, food, urbanization, energy, etc., depends on the proper exploitation and investment of the human element in society. The phenomenon of undevelopment of societies is due to lack of importance given to human element. societies not to pay attention to the human factor and not to provide him with the necessary competencies, knowledge , and positive directions , and not to develop his skills and capabilities, and invest them in solving problems and obstacles related to the dimensions of development in society will end as an undeveloped society.

It is well known that the system's outputs are largely affected by the quality of its inputs as well as the role of operations in that. Therefore, it is assumed that any organization - whatever the nature of its activity -is assumed to provide some important elements in its inputs as basic requirements, which must be available in order to convert it to outputs in a product form, or services compatible with the needs of the labor market (Ismail et al. 2009).

Knowledge-based economies are an inexhaustible resource that societies and nations seek to acquire, and hence it is important to build an educational system that sharpens the energies of each learner, and develops them to the maximum that they can reach, without accepting regular levels of success and providing society with multi-skilled graduates who are able to permanent learning, and this requires a flexible educational system and preparation that makes the graduate able to adapt quickly to the rapid technological development, which has a great impact on 
social, cultural and living systems, consumption habits, the meaning and position of work (Ammar 2000 \& AlHamali 2008).

The process of improving the educational system indicates the studied growth on scientific grounds, and includes comprehensive and integrated development in all of the academic, economic, political and social fields. It can be said that it is a comprehensive process of change that is planned to improve its educational outcomes, as it is a process of emanating and detonating the potentials inherent in students in order to create a better situation for them and society to ensure a decent living. Therefore, the process of improving the educational system depends strongly on the systematic scientific planning in order to Programs designed for them reach their goals, and to produce able students who can confront life's challenges, changes that happen around them positively and effectively, and help them think positively and creatively, and change their perception from a superficial view to a deeper and different look to the life around them (National Quality Assurance and Accreditation 2004).

The poor academic achievement of students has many reasons, including: educational, which includes the school and its educational body, its curriculum, and the foundations on which the educational system is based, such as the lack of some curriculum for excitement, not using modern teaching methods, and the use of teachers needing more training and experience, and weakness of academic and educational guidance, in addition to the prevailing system of examinations that focuses on memorization (Obeidat \& Al-Rashdan 1993; Morsi 1998; Khatiba \& Al-Saud 2009). Among them are reasons related to the student, which include psychological reasons, such as students 'aversion to study and preparing lessons, lack of attention, fear of failure, and anxiety of the test, in addition to the weakness of students' interest in school exams conducted by the teacher, and subjective reasons such as poor general mental ability required for achievement, and disorders Physical development, physical impairments, and the study type inconsistent with students' inclinations (Al-Zaabalawi 1998; Al-Bawat 2006). Other reasons include family and social reasons, as family and society have a role in the problem of poor academic achievement, such as neglecting the follow-up of children, and lack of interest in their educational future, in addition to the weak link between the family and the school, consequently a poor follow up of parents following the behavior of their children in school, and the low level of parents 'ambitions, or the level of their education, All these factors are associated with poor achievement in students in schools (Morsi 1998; Al-Bawat 2006; Al-Tamimi 2014).

Since the contemporary world is witnessing many changes and developments in the educational, economical, social, cultural, political, administrative and educational fields, these changes have changed and replaced many concepts and constants that have been stable in minds for many years, and have caused many problems, most notably the inability to keeping abreast with developments regarding public education and academic achievement of school students, and understanding their true motives and interpretation, as well as adapting to them.

The goal of education reform and development is a global and local requirement in every time and place; for what the education system in any country represents an important pillar and a strong indicator for the safety of society with its institutions and individuals. However, one of the most important obstacles that can face the efforts of educational reform is the phenomenon of low academic achievement of students, as this phenomenon has taken on the global characteristic, so that almost no educational system is safe from its negative effects, and what increases seriousness of this phenomenon is the waste and loss it causes in human and material resources, as well as concern over the future of students in completing their studies, joining the labor market, and the degree to which societies are able to keep pace with and compete with the tremendous progress in various areas, has led to an increased Interest in the phenomenon of low academic achievement among school students (Covington \& Emlin 2006).

Moreover, modern and pioneering institutions seek to bring about fundamental changes and modernize the structure of their operations and information to keep pace with the changes taking place in their surrounding environment, and increase their ability to compete and survive, and there is no doubt that the change aims primarily to provide the institutions with the flexibility and ability necessary to embody their goals and enhance their culture, to serve their furure outlook, and its strategic plans to enhance their competitive advantage, and there are many modern administrative methods that aim to achieve these goals like total quality management and the reengineering of administrative processes. In view of the huge technological development in the recent period and the emergence of the Internet, the method of reengineering administrative processes (reengineering) has been used in many organizations, because of its great role in reducing costs, saving time and effort, and improving quality in administrative processes (Al-Dajni 2010). This may be one of the most important things that the education sector in Jordan needs to develop the entire education system and thus this is reflected in the improvement of academic achievement among school students, and the improvement of educational outcomes that are the basis of the educational system. 
The concept of reengineering administrative processes (reengineering) is one of the entry points to development that focuses on the rapid and radical redesign of strategic administrative operations, as well as systems, policies and organizational structures, with the aim of improving performance and increasing productivity in its quantity and quality in the organization, at the lowest cost, time and effort (Hussein 2007). In view of the profound and rapid changes that have occurred in the educational system, and given the importance of the entire educational system, it is no longer possible to meet the challenges in the traditional ways that have prevailed for a long period of time. What the education system needs is to look at the problems in an organized manner, working to generate knowledge, organize, acquire and deal with knowledge, with the aim of reaching a level of an in-depth understanding of its problems and taking the appropriate decision regarding them (Al-Tunaiji 2008); (Abdous \& Wuhe 2008).

The re-engineering of administrative processes (reengineering) is considered one of the educational methods to administrative and educational development, which differs from other methods, as this method aims to reach radical improvements in the education system in the following areas: time required to provide service, reduce costs, and improve the quality of service produced. This method of development begins with fundamental questions about the feasibility of the necessity of the existence of every unit of the educational system and its rationale, and this requires a review of the functions, organizational structure, technology, policies used, and others. This may be at the quantitative level, or at the level of specific units. This method also focuses on developing the processes through which the educational institution's goals are achieved.

Several authors have described reengineering in different ways: re-engineering, management engineering, and engineering. As for reengineering, it is a new Arabic word composed of the words engineering and management, and it is in fact a translation of the English term (Business Reengineering). Hence, the word, even if it does not mean administrative engineering with literal translation, however, it means a radical redesign of the process accompanying administrative systems. Hammer \& Champy are considred the pioneer in management engineering (engineering), and this entrance appeared in the mid-1990s (Hussain 2006).

Reengineering differs from traditional development methods, as it is the process that starts from the point of zero, and focuses on administrative processes for the highest activities and is concerned with results, and the need of service recipients, and is based on structuring work on the basis of the process as a whole, and is characterized by it being based on skepticism about the legitimacy of the entire administrative process, and may need Often times to change, rebuild or cancel (Sultan 2001). The most notable feature of reengineering administrative processes from others is that they enable finding radical solutions to problems through seeing the comprehensive picture of the work style of different organizations, as reengineering processes helps to break out of the routine, a narrow view of work, lack of comprehensiveness, and quick solutions to work problems, And other traditional administrative systems and methods (Abdul Hafeez 2009).

The emergence of the age of knowledge and the great shift in educational thought requires reconsideration of the education system in Jordan, in view of the position occupied by this system that touches and changes the present, and extends its effects to the future, and is considered as the essence of the educational process, therefore requires a careful pause to study the mechanisms of the educational decision makin industry and its implementation in Jordanian schools, with a view to reviewing all available alternatives, and adopting an integrated system of stages and appropriate strategies to formulate the educational decision in the light of a comprehensive view of the educational process and its internal and external environment, not in light of an insight based on experience and personal analysis only. The issue of reengineering the system of education to improve academic achievement may be considered one of the most important topics that educational decision-makers are supposed to attach to more importance, as it relates to the efficiency and effectiveness of the education system as a whole (Al-Khatib 2001; Al-Azzawi 2006; Hebron 2008). Consequently, reengineering may be the most effective way to achieve the goals by introducing radical adjustments to the entire educational system, ensuring less cost, shorter time, and higher returns to improve academic achievement among school students. This is what justified the researcher to undertake this study, and the current study comes to develop a reengineering model for the education system to improve academic achievement of students in Jordanian schools.

\section{Study Problem:}

In light of the foregoing, the importance of education stems from the fact that it is considred the source of human energy and an active component of social, economic, political, environmental, and technological development. If human development is a process of developing the skills, knowledge, and capabilities of individuals, the entity that is able to achieve these characteristics is the Ministry of Education represented by its schools. The more 
increase of quality and quality of education, and he has succeeded in providing its members with these characteristics and features, the more increase of level of human development should happen, which in turn works to push the economical, social, political, environmental and technological movements forward.

The importance of high-quality education for students in Jordan cannot be denied, as students who receive high quality education are more likely to obtain employment opportunities in the future, and thus contribute to supporting the economic wealth and prosperity of the country, and this requires more efforts to advance the educational process in its entirety, with minimal effort, cost and the highest quality by working on reengineering the education system. Educational studies, such as the study of: Al-Karimin (2006) and Al-Khawaja (2008), also indicate that the application of process engineering (reengineering) achieves many benefits that accrue to educational institutions efficiently and effectively in their performance and works to improve the academic achievement of their students, and also maintains the survival And the continued ability of educational institutions to face the emerging challenges that they may face.

Despite all the aspects of care and attention that the education system has received in Jordan, it still faces many obstacles, and the phenomenon of low academic achievement is one of those challenges. Accordingly, the problem of study is determined in the following question: What is the appropriate model of reengineering for the education system to improve the achievement of students in Jordanian schools? From this question the following questions arise:

1. What is the reality of the education system in Jordanian schools with respect to: (students, teachers, the curriculum, exams, and school administration) as seen by both principals and teachers?

2. Are there statistically significant differences in the level $(\alpha \leq 0.05)$ in the reality of the education system in Jordanian schools as seen by both teachers and principals due to the nature of the type of job variable (teacher, principal)?

3. What is the appropriate reengineering model for the education system to improve academic achievement of students in Jordanian schools?

\section{Importance of the study:}

It is hoped that the following parties will benefit from the results of this study:

1. Educational decision-makers in Ministry of Education, by making use of the reengineering model, as this study provides them with a ready-made model for reengineering the education system; to improve academic achievement of students in Jordanian school.

2. Principals and teachers, through their knowledge of the reasons for poor student achievement, by choosing the best, most effective and useful teaching methods for them.

3. The local community and parents in knowing and identifying the most important social, economical and family factors that have a role in the weak academic achievement of their children to avoid and overcome them, and define the proposed solutions.

4. Researchers in general, as it is hoped that the study raises the desire to conduct more research related to the subject of reengineering the system to improve academic achievement ofstudents in Jordanian schools to work on developing the stystem to a better level than it is.

\section{Objectives of the study:}

This study aims to reveal the following points:

The reality of the education system in Jordanian schools with respect to: (students, teachers, the curriculum, exams, and school administration), as seen by both principals and teachers.

- There are statistically significant differences in the level of $(\alpha \leq 0.05)$ in the reality of the education system in Jordanian schools, due to the nature of the variable of the type of job (teacher, principal).

Developing a suitable reengineering model for the education system to improve academic achievement of students in Jordanian schools. 


\section{Limits of the study:}

- The generalization of study results is determined by the following limits:

Human boundaries: The study was limited to principals and teachers in Jordanian schools affiliated to the Ministry of Education.

- Spatial limits: Jordanian public schools affiliated to the Ministry of Education in the Central Region, including (the capital, Balqa, Zarqa, Madaba).

Time limits: the period during which the researcher applied the study, which is represented in the academic year (2018-2019).

\section{Definition of study terms:}

Following is a definition of the terms of the study:

The model: As stated in Al-Khawaja $(2008,7)$, Krone defines the model as "a scheme through which the main steps of reengineering the educational decision-making process and the factors affecting it are clear. It is a planned, organized and accurate perception of reality, and a simplified part of the truth that includes important aspects that help in understanding and controlling the studied phenomenon, which is a symbolic approximation to the actual situation, and it is a tool of thinking and analysis, which requires in its construction a creative and innovative mental ability.

- Reengineering (Reengineering Administrative Processes): It is defined as "fundamentally rethinking and radically redesigning the educational decision-making process, to work on substantial improvements in the performance of appropriate procedures to influencing contemporary issues such as cost, quality, service, and speed" (Hummer \& Stephen 2000, 14).

As Procedurally, reengineering the education system was intended: adopting an integrated system of steps that includes identifying educational problems and gathering the necessary information on them, proposing and evaluating a set of alternatives, choosing the most appropriate alternative based on a set of criteria, and the influencing elements that include legislation and laws, and the conditions of the target group, the philosophy of Ministry of Education, the service of the interest of the educational institution (the school) and its vision, and work to take appropriate decisions in this regard through mechanisms that include preparing the internal and external environment of the educational institution (the school), and defining tasks and responsibilities of workers in the educational institution (school), and develop a plan for the implementation of these decisions, and modify the decisions taken if this is required; in order to develop the education system and to improve the academic achievement of the students, as the study tool will determine it.

- The education system: Al-Khatib (2004) defines the education system as: the framework that includes all the elements of the educational process and its components - goals, objectives, and regulations, students and teachers, and various workers in the education sector, school buildings and material capabilities, and curriculum, The functional relationships between all these components, and the interaction, cooperation and complementarity that takes place between them with a view to achieving specific goals and objectives previously drawn which are the goals of education in a country.

- Academic achievement: Academic achievement is defined as a scientific effort achieved for the individual through education, study and training practices in the scope of an educational field, which achieves the benefit gained by the learner from the educational, and training lessons and directions given or prescribed to him (Falih and Zaki 2004).

\section{Previous studies:}

The researcher reviewed a set of studies related to the reengineering of the education system to improve academic achievement of students in Jordanian schools, accordingly below a review of these studies in chronological order from oldest to most recent.

Al-Karimain (2006) conducted a study entitled (a model for reengineering educational decision in the Ministry of Education at the level of senior management in Jordan). The study sample consisted of (48) individuals from the higher management in the Ministry of Education, and the study reached the following results: there was a variance in the degree of higher management practice for reengineering educational decisions in the ministry, while the average of application of of reengineering decisions was (3.21), for the ethical value system (3.26), for the 
characteristics of information (2.85), for influencing elements (3.07), for decisions Support systems (2.85), sources of information reengineering decisions (2.82), and to present the resolution (2.86), and the difficulties faced by principals were low and an arithmetic mean (2.29).

Roqaya Al-Maaita (2006) conducted a study entitled "Developing an educational management strategy to increase the efficiency of workers in the middle administration in the Jordanian Ministry of Education in the methodology of human engineering." It aimed to find an educational managerial strategy that leads to increasing the efficiency of workers in the middle educational departments, through developing and changing The administrative work related to them, in the light of human engineering. The sample of the study consisted of (153) individuals from the directors of departments, directors of education, and specialized directors in headquarters of the ministries, and the directorates of education affiliated to them, and the study reached the following result: the middle administrion in the ministry of education has a low degree of managerial competence in all areas of administration, as a concept was proposed to plan the services of the middle departments in the Ministry of Education, a strategy was developed to increase the efficiency of workers and to develop and change administrative work in light of the concept of human engineering.

Al-Tunaiji (2008) conducted a study entitled "A proposed model for developing the performance of workers in the Ministry of Higher Education and Scientific Research in the United Arab Emirates in the light of the methodology of re-engineering administrative processes." The study community consisted of all workers in the Ministry of Higher Education and Scientific Research in the UAE The United Arab Emirates for the year (2007/2008), whose number is (70) employees. The sample of the study consisted of (50) employees, and they constitute $(71 \%)$ of the study population. The study found that the reality of administrative development in the Ministry of Higher Education and Scientific Research in the United Arab Emirates was generally high, and the degree of approval of the proposed model for developing the performance of workers in the Ministry of Higher Education and Scientific Research in the United Arab Emirates in the light of the methodology of re-engineering administative operations at overall was high.

Tarawneh, Khater, and Tuwayqat (2011) conducted a study entitled "The degree of application of the provisions for the reengineering of administrative processes in developing the performance of workers in Amman foruth Directorate of Education". aimed at determining the degree of application of the items of the reengineering of administrative processes in developing the performance of workers in Amman fourth Directorate of Education, the study sample consisted of (150) male and female employees working in Amman fourth Directorate of Education, and the study found that the degree of application of the items of the reengineering of administrative processes in the total was generally average, and there were no statistically significant differences among the mean ,for the degree of applying the items of reengineering of administrative processes in developing the performance of workers in Amman fourth Directorate of Education, according to the gender variable, and theier were no statistically significant differences between the mean levels of the application of the items of administrative process reengineering in developing the performance of workers In Amman fourth directorate of education, according to the variable of the educational qualification in all fields, except for the total degree of fields combined, and the field of application, as the difference was statistically significant, and in favor of postgraduate certificate holders.

The study also showed that there were no statistically significant differences between the mean, to the degree of application of the provisions for the re-engineering of administrative processes in developing the performance of workers in the Amman fourth Directorate of Education, depending on the variable of the nature of the work, and the presence of statistically significant differences between the average degree of application of the items of reengineering of administrative processes in developing The performance of workers in the Amman Fourth Directorate of Education, according to the variables of years of experience in the total degree of domains combined, with the exception of the evaluation field, and for the benefit of those with experience of (10) years or more.

Oubedda \& Erraha \& Khalfaoui (2012) conducted a study entitled "Analyzing Intelligent Data for Decision Making in Universities", which aimed to develop an information system that helps in decision-making at the university; to develop a model consists of related parties in the university (teachers ,students, and administrators) and this system is based on the relationship between actors and their activities, and aimed to provide information panels for administrators in universities that improve the quality of education, as well as to enable decision makers and university administrators to obtain valuable information that can be consulted with confidence, as part of the decision-making process, and the study concluded to design a model for the database accessible to decision makers in universities to facilitate the process of decision-making. 
Alam (2012) conducted a qualitative study entitled "Obstacles facing students in learning and academic achievement at the University of Peshawar", which aimed to identify the obstacles related to academic achievement in a sample of (30)male students and (30) female students from secondary schools in Pakistan. The results of the interviews with the study members revealed that the most important obstacles to achievement were arranged as follows: study tests, poor guidance and professional counseling since school days, lack of classroom participation, strict teacher methods, extra-curricular activities, and lack of social and family support.

Ahmed and Rayes (2013) conducted a study entitled "Reasons for the low level of academic achievement of high school students from the point of view of teachers and students". It aimed to know the reasons for the low level of academic achievement of high school students from the viewpoint of teachers, male and female students in the Samarra City Center- Iraq -. The sample of the study consisted of (156) male and female teachers, and (367) male and female students. The results showed that many social, psychological, and school factors combined contributed to the low level of academic achievement of secondary school students, and among the reasons included were the proliferation of mobile phones, amusement and entertainment among students, the large number of distractions, the lack of intelligene stimuli for students, and the psychological effects due to the political and economic conditions around them.

Peter \& Ruth (2013) conducted a study entitled "The effect of the family on the achievement of American high school students in Edo North Senatorial District". It aimed to research the obstacles related to academic achievement of high school students in America. The study sample consisted of (260) Male and female students, and the results revealed that there were statistically significant differences in academic achievement attributable to the variables (family size and social and economic level) and for the benefit of students with better economic and social level, and less family size.

The Rababaa (2015) conducted a study entitled "Obstacles to Academic Achievement among High School Students (Tawjihi) from the Point of View of Successful and Unsuccessful Students and Their Parents," aimed at identifying the obstacles associated with the academic achievement of high school students from the viewpoint of successful and unsuccessful students, and their parents In Irbid governorate for the academic year (2015/2014), and whether there are statistically significant differences in these obstacles due to gender variables, place of residence, and study branch. The study problem emerged from the crisis caused by the results of high school at the social and national levels, as a result of the noticeable decline in academic achievement. To achieve the aims of the study, the researcher prepared a measure of the obstacles related to the academic achievement of (36) paragraphs and they were distributed in the three areas: self, educational and social. The sample of the study consisted of (1022) participants, of whom (511) were male and female students, and (511) parents.

The results showed the presence of an average level of obstacles related to educational achievement among successful students compared to those unsuccessful who showed a high level of obstacles, and the absence of statistically significant differences in the level of obstacles for whole attributable to the variables of gender and location .while statistically significant differences in both self and educational obstacles attributable to the variable of the branch of study for the benefit of information management students. With regard to unsuccessful students, the results showed that there were no statistically significant differences on the level of academic achievement barriers as a whole, and on any of its fields due to the variables of the study. Also, there was an average level in the obstacles of academic achievement among the parents of successful students, and a high level in the parents of unsuccessful students, and there was an absence of statistically significant differences in the level of obstacles for whole, and in all areas to the variable of gender.

It is noted from the results of previous studies related to academic achievement among students that there is agreement on the existence of a number of obstacles related to academic achievement among school students: such as the obstacles related to the student, the educational environment, in addition to family and social factors. As in studies (Peter \& Ruth 2013; Ahmed \& Reis 2013). The results of previous studies also differed in identifying the most influential obstacles to academic achievement, due to different environments and time of application.

It is also noted from previous studies related to reengineering, that the methodology of reengineering administrative processes gained the attention of Arab and foreign researchers, as previous studies focused on aspects of applying the methodology of reengineering administrative process, some focused on areas of administrative development in the industrial, trade, educational sectors and others. Also it is noted by the interest of researchers in studying educational institutions from all aspects, which indicates the importance of their role in bringing about the positive change required in societies. Some studies indicated that the reasons for the low achievement of students are due to factors related to teachers, curriculum, exams, families, and students themselves. The current study has benefited from the studies presented by building its tools and discussing its 
results, and the current study is distinguished as a qualitative study that is unique - according to the researcher's knowledge - by developing a reengineering model for the education system to improve academic achievement of students in Jordanian schools.

\section{Method and procedures:}

7.1 Study methodology: To achieve the goal of the study, which is to develop a reengineering model for the education system to improve the academic achievement of students in Jordanian school, a developmental survey research approach has been adopted.

7.2 Study community: The study community consisted of all principals and teachers of schools affiliated to the Ministry of Education in the Central Region in Jordan, and they include (the capital, Balqa, Zarqa, Madaba), and their number (40499). Table (1) shows the distribution of study population individuals according to the variable of the job type (principal, teacher), by referring to the website of the Jordanian Ministry of Education (www.moe.gov.jo/ar/reports), according to the latest statistics available for the year (2018/2019).

Table (1): Distribution of the study population individuals according to type of job

\begin{tabular}{|c|c|c|}
\hline Variable & sum of teachers & $\begin{array}{c}\text { Sum of } \\
\text { principals }\end{array}$ \\
\hline Job type & 36792 & 3707 \\
\hline \multicolumn{2}{|c|}{ Total } & 40499 \\
\hline
\end{tabular}

\section{Study Sample:}

A random sample was chosen from the study community, using the statistical tables (Al-Dhahyan, 1999). The study sample consisted of (783) teachers and principals from Jordanian schools. Table (2) shows the distribution of the study sample individuals.

Table (2): The study sample individuals were divided according to type of job

\begin{tabular}{|l|l|l|l|}
\hline \multirow{2}{*}{ Variable } & \multicolumn{2}{|c|}{ job type } & Total \\
\hline \multirow{2}{*}{ Job type } & Teachers & Principals & \multirow{2}{*}{783} \\
\cline { 2 - 3 } & 651 & 132 & \\
\hline
\end{tabular}

\section{Study tool:}

To achieve the objectives of the study, the study tool was designed by referring to the educational literature related to the subject of the study, as well as making use of the tools of previous studies, related to the topic of reengineering the system of education and improving academic achievement among students, such as the study of Al-Karimin (2006), Al-Khawaja (2008), Al-Tenaiji (2008). Al-Dajani (2010) and Ahmed and Rayes (2013). The study tool included in its final form (25) paragraphs, which included five axes for each axis (five paragraphs), which are as follows: the first axis (the reality of the education system in Jordanian schools with regards to students), the second axis (the reality of the education system in Jordanian schools with regards to teachers ,The third axis (the reality of the education system in Jordanian schools with regards to the curriculum), the fourth axis (the reality of the education system in Jordanian schools with regards to exams), and the fifth axis (the reality of the education system in Jordanian schools with regards to school administration). Each paragraph was given a weight listed according to the five-letter scale. The highest response gradient (always) was given five degrees, and the lowest response gradient (never) was given one degree. The following ranking was used for the purposes of classifying the arithmetic mean on the study tool, its fields and paragraphs, and the aim was to judge the responses of teachers and principals. 
9.1 The standard for judging the degree of appreciation:

Equation $(1-5) \div 3=1.3$ was adopted, and accordingly:

-If the mean value is less than (2.33), then the estimation is low.

-If the mean value is greater or equal to (2.33) and less than (3.67), then the estimate is average.

-If the mean value is greater or equal to (3.67), then the estimation is high.

Validity of the study tool: The tool was presented in its initial form to (11) specialized arbitrators, who are members of the teaching staff in Jordanian universities, and to ensure that the tool measures the goal to be measured, and to judge the study tool in terms of: the degree of consistency of paragraphs with the axis concerned, and the degree of Its suitability for study, clarity of paragraphs, and the correctness of linguistic formulation, and there was scope for any proposed additions or amendments that they find appropriate and necessary to complete the study tool, and an agreement criterion $(80 \%)$ of arbitrators was adopted to make any amendment to the study tool, after making the amendments recommended by the arbitrators from delete ,and/or edit the formulation of some paragraphs, (6) paragraphs were canceled from the axes of the study, so the tool became in its final form consisting of (25) paragraphs, as each axis included (5) paragraphs.

9.2 stability of the study tool: The tool was applied to a reconnaissance sample consisting of (30) individuals to extract the stability of the tool, and the internal consistency coefficient was calculated for it, through the use of the Gronbach Alpha equation for the axes of the study tool. Table (3) shows stability coefficient values as follows:

Table (3): Stability coefficient values

\begin{tabular}{|l|l|l|}
\hline \multicolumn{1}{|c|}{ number } & \multicolumn{1}{|c|}{ Axis } & \multicolumn{1}{|c|}{$\begin{array}{c}\text { Stability } \\
\text { coefficient }\end{array}$} \\
\hline 1 & $\begin{array}{l}\text { The reality of the education system in Jordanian schools with } \\
\text { regards to students. }\end{array}$ & 0.98 \\
\hline 2 & $\begin{array}{l}\text { The reality of the education system in Jordanian schools with } \\
\text { regards to teachers. }\end{array}$ & 0.95 \\
\hline 4 & $\begin{array}{l}\text { The reality of the education system in Jordanian schools with } \\
\text { regards to the curriculum. }\end{array}$ & 0.96 \\
\hline 5 & $\begin{array}{l}\text { The reality of the education system in Jordanian schools with } \\
\text { regards to exams. }\end{array}$ & 0.97 \\
\hline Total & $\begin{array}{l}\text { The reality of the education system in Jordanian schools with } \\
\text { regards to school administration }\end{array}$ & 0.98 \\
\hline
\end{tabular}

Table (3) shows that the values of the stability coefficients are suitable for the purposes of the study.

\section{Study variables:}

The study included the following variables:

The independent variable: responses of respondents to the areas of the study tool.

The dependent variable: a reengineering model of the education system to improve academic achievement of students in Jordanian schools.

- Intermediate variables: (job type variable: principal / teacher).

\section{Statistical treatments:}

After developing the study tool and extracting honesty and reliability, it was distributed to the members of the study sample, and after completing the process of collecting the necessary data and information about the variables of this study, it was coded and entered into the computer to extract statistical results, as the statistical methods were used, within the statistical package program for social sciences (SPSS), and then the data obtained was processed, and the following statistical methods were used:

- Arithmetic mean to determine the importance of the paragraphs mentioned in the questionnaire, as well as the standard deviation to indicate the degree of dispersion of answers from their mean. 
- T-test, in order to test the degree of statistically significant differences in the answers of the study sample, which are attributed (to the type of job) of the sample being studied.

\section{The results of the study and its discussion:}

The study aimed to develop a reengineering model for the education system to improve academic achievement of students in Jordanian schools and to facilitate the presentation of the results of this study, it was divided according to the study questions, and it reached the following results:

First: The results of the first question and its discussion, which states the following: "What is the reality of the education system in Jordanian schools with respect to: (students, teachers, curriculum, exams, and school administration), as seen by both principals and teachers?"

To answer the question, the arithmetic mean, and the standard deviations of the reality of the education system in Jordanian schools, was calculated on each axis and paragraph, and Table (4) shows the results of that, as follows:

Table (4) Arithmetic mean and standard deviations for the reality of the education system in Jordanian schools, as seen by both principals and teachers, for the axes and for the college

\begin{tabular}{|l|l|l|l|l|l|}
\hline $\begin{array}{c}\text { Axix } \\
\text { number }\end{array}$ & \multicolumn{1}{|c|}{ Axis name } & $\begin{array}{l}\text { standard } \\
\text { deviation }\end{array}$ & SMA & Arrangement & Appreciation \\
\hline 1 & $\begin{array}{l}\text { The reality of the education } \\
\text { system in Jordanian schools with } \\
\text { regards to students. }\end{array}$ & 0.72 & 3.75 & 1 & High \\
\hline 2 & $\begin{array}{l}\text { The reality of the education } \\
\text { system in Jordanian schools with } \\
\text { regards to the curriculum. }\end{array}$ & 0.77 & 3.69 & 2 & High \\
\hline 3 & $\begin{array}{l}\text { The reality of the education } \\
\text { system in Jordanian schools with } \\
\text { regards to teachers. }\end{array}$ & 0.77 & 3.43 & Average & Average \\
\hline 4 & $\begin{array}{l}\text { The reality of the education } \\
\text { system in Jordanian schools with } \\
\text { regards to exams. }\end{array}$ & 0.93 & 2.97 & Average & Average \\
\hline 5 & $\begin{array}{l}\text { The reality of the education } \\
\text { system in Jordanian schools with } \\
\text { regards to school administration. }\end{array}$ & 1.09 & 2.81 & Average & Average \\
\hline Total & & 0.84 & 3.33 & Average & \\
\hline
\end{tabular}

It is clear from Table (4) that the two axes of the study - which indicated the existence of educational problems came with a high degree, a degree indicating the presence of educational problems in a high degree, while the rest of the three axes came with an average degree, which is not satisfactory and also not weak. the average sample responses The study shows that the Jordanian schools did not reach their goal, despite the steps taken to raise the level of education, they still did not achieve what they hoped for. The axis: "The reality of the education system in Jordanian schools with regard to students" ranked first with a high rating, meaning that the degree of existance of educational problems (with regard to students) came high, with an average of (3.75) and a standard deviation of (0.72).

This may be attributed to the fact that students are the focus of the educational learning process, its fruit and the purpose of its existence. Most of the educational problems were focused on them. The purpose of education is to prepare students to face life and its challenges in the present and future, develop their skills, and reinforce their integrated growth. Since students are the focus of the educational process and in view of the importance of this element in the educational process, they are the most affected and exposed to educational problems. As a significant proportion of school students suffers from poor possession of basic skills, such as reading, writing and numeracy skills; perhaps the reason for this lies in educational policies related to the automatic transfer of students to higher classes, without ensuring that they have these skills or ascertaining their control of the competencies that enable them to successfully pursue academic life. Whereas, the fifth axis, "The reality of the education system in 
Jordanian schools with regard to school administration" came in the last rank, with an average estimate, and arithmetic average of (2.81) and a standard deviation of (1.09).

It is a degree that is neither satisfactory nor weak, and this may be due to the weak cooperation between school administration and the local community, and due to the negative impact from the difficult economic conditions the families of some students have with affects the learning of their children; this in turn negatively affects their academic achievement, and thus the entire education system. School administration is a foundation upon which society relies in achieving its strategic goals in preparing generations for a better life that is capable of meeting the requirements of life. In order to complete this construction successfully, the school administration needs an efficient principal, a leader person who is capable of leading the educational process in order to achieve the goals in the easiest ways and the lowest costs. The school principal plays the primary role in leading efforts and directing them to the right direction, and works to unite forces and exert energies of the workers with him In order to improve their work and his students on the one hand and the whole society on the other hand.

Results related to the axis of the reality of the education system in Jordanian schools with regard to students: Table (5) presents them:

Table (5) arithmetic mean and standard deviations for the reality of the education system in Jordanian schools, as seen by both ministers and teachers, for the first axis paragraphs: "The reality of the education system in Jordanian schools with regards to students."

\begin{tabular}{|l|l|l|l|l|l|}
\hline No. & \multicolumn{1}{|c|}{ Paragraphs } & $\begin{array}{l}\text { standard } \\
\text { deviation }\end{array}$ & SMA & arrangement & Appreciation \\
\hline 1 & $\begin{array}{l}\text { Students suffer from poor academic and } \\
\text { cognitive foundation in the previous } \\
\text { grades. }\end{array}$ & 0.75 & 3.98 & 1 & High \\
\hline 2 & $\begin{array}{l}\text { Students suffer from poor motivation to } \\
\text { learn and study. }\end{array}$ & 0.80 & 3.84 & 2 & High \\
\hline 3 & $\begin{array}{l}\text { Students suffer from the lack of concern } \\
\text { of their parents and follow-up on their } \\
\text { studies. }\end{array}$ & 0.77 & 3.70 & 3 & High \\
\hline 4 & $\begin{array}{l}\text { Students accompany bad friends } \\
\text { Students suffer from distraction inside }\end{array}$ & 0.78 & 3.60 & 5 & Average \\
\hline 5 & $\begin{array}{l}\text { Stuge } \\
\text { the classroom. }\end{array}$ & 3.74 & High & \\
\hline Total
\end{tabular}

It is clear from Table (5) that Paragraph No. (1) Which states "Students suffer from poor academic and cognitive foundation in the previous grades" came first with a high estimate, with an average of (3.98) and a standard deviation of (0.75). This may be due to the reasons related to the student himself, such as his poor mental capabilities, or his weak intelligence, or his inability to absorb the information he receives. In addition to the suffering of some students from other physical problems such as poor eyesight, poor hearing, or poor physical structure, which causes fatigue and exhaustion for most of the time and thus affects his academic achievement? Also, the lack of a student getting enough sleep leads to a weak concentration in the classroom.

While some students may have psychological problems that affect their ability to learn properly such as weak personality, frustration, stress, anxiety or loss of interest in studying, for various reasons such as: hate the subject, the teacher, school, or feeling upset by some students surrounding. In addition, some students may suffer from social problems such as separation of parents, the presence of family problems, or exposure to family violence, discrimination and injustice within the family, which causes them to be distracted in the classroom.

There are reasons related to the family, such as the lack of interest of the parents or one of them to study, because they are busy with their work or they did not complet their study, since the student needs to follow up at home to achieve the purpose of teaching, he/she is also occupied with external work that takes time instead of being employed in the study, such as: performing housework or participating in work to increase family income. These affect his/her understanding capacity. In addition to some reasons that relate to the school as its lack of encouraging facilities that the student loves, the lack of organization and different teaching methods, as students need different teaching methods to clarify the information and embed it in the minds. 
The automatic upgrade in the basic stage that has been in effect for a long time, has also contributed to the presence of educational outcomes that are unable to keep pace with the educational level in the subsequent educational stages, and other reasons negatively affects the follow-up and establishment of the student knowledge and skill so that he can follow the subsequent educational stages successfully.

Whereas, paragraph (5) which states, "Students suffer from distraction inside the classroom," came in the last rank with an average estimate, and an arithmetic average of (3.60) and a standard deviation of (0.78). This may be due to internal reasons related to the student: such as organic factors, for instance those related to nervous maturity, or difficulties in cognition, or psychological factors such as anxiety, insecurity, and daydreaming. Dispersed attention means the inability to continuously pay attention or focus on a stimulus in the environment and isolate other stimuluses , so the student feels as if he is struggling to maintain his focus and attention by his weak ability to do so, consequently avoiding any task that requires attention. The student's physical condition during the learning session (such as feeling hungry - drowsiness or extreme fatigue - cold or free) are all factors that affect the student's attention inside the classroom. There are also external reasons related to the learning process and the class environment: such as the nature of the teaching material, inappropriate teaching method, the absence of appropriate educational techniques, the large number of distractions in the classroom, the presence of an atmosphere of anxiety and tension in the classroom, or the many problems inside and outside the classroom, The presence of inappropriate teaching aids, or the nature of the discipline pattern prevailing in the classroom. All these factors influence the focus of the student's attention inside the classroom.

Results related to the axis of the reality of the education system in Jordanian schools with regard to teachers: Table (6) presents them:

Table (6) arithmetic averages and standard deviations for the reality of the education system in Jordanian schools, as seen by both principals and teachers, for the second axis paragraphs: "The reality of the education system in Jordanian schools in relation to teachers."

\begin{tabular}{|c|c|c|c|c|c|}
\hline No. & paragraphs & $\begin{array}{l}\text { standard } \\
\text { deviation }\end{array}$ & SMA & Arrangement & Appreciation \\
\hline 9 & $\begin{array}{l}\text { Teacher suffers from } \\
\text { vercrowding in the classroom. }\end{array}$ & 0.88 & 3.85 & 1 & High \\
\hline 7 & $\begin{array}{l}\text { Teachers rely on traditional } \\
\text { ethods of teaching such as } \\
\text { memorization. }\end{array}$ & 0.78 & 3.71 & 2. & High \\
\hline 6 & $\begin{array}{l}\text { There is a shortage of teachers } \\
\text { at the beginning of the } \\
\text { semester. }\end{array}$ & 0.82 & 3.52 & 3 & Average \\
\hline 8 & $\begin{array}{l}\text { Weakness prevails in the good } \\
\text { relationship between teachers } \\
\text { and students represented by } \\
\text { mutual respect. }\end{array}$ & 0.92 & 3.29 & 4 & Average \\
\hline 10 & $\begin{array}{l}\text { Teacher finds difficulties to } \\
\text { control students in the } \\
\text { classroom. }\end{array}$ & 0.82 & 2.78 & 5 & Average \\
\hline \multicolumn{2}{|c|}{ Average } & 0.77 & 3.43 & \multicolumn{2}{|l|}{ Total } \\
\hline
\end{tabular}

It is clear from Table (6) that paragraph (9) which states "The teacher suffers from overcrowding of students in the classroom" came first with a high estimate, with an arithimtic average of (3.85) and a standard deviation of (0.88). This may be due to the constant suffering of teachers and principals from the problem of overcrowding of students in the classroom and this leads to a low quality of education, and the ability of teachers to deliver lessons in a good way, and this has a negative impact on the academic achievement of students.

Whereas, paragraph (10), which states, "It is difficult for the teacher to control the students inside the classroom," came in the last rank with an average estimate, with an arithimtic average of (2.78) and a standard deviation of (0.82). This may be attributed perhaps to reasons that may be attributed to the student, teacher, class environment, school administration, or society in general, for each teacher the task of deducing the reasons that 
may hinder the course of the session, which may cause chaos inside the classroom, and to work to find appropriate solutions to it.

Results related to the axis of the reality of the education system in Jordanian schools in relation to the school curriculum: Table (7) presents them:

Table (7) arithmetic mean and standard deviations for the reality of the education system in Jordanian schools, as seen by both principals and teachers, for the third axis paragraphs: "The reality of the education system in Jordanian schools in relation to the curriculum".

\begin{tabular}{|l|l|l|l|l|l|}
\hline No. & paragraphs & $\begin{array}{l}\text { standard } \\
\text { deviation }\end{array}$ & SMA & Arrangement & Apprectiation \\
\hline 14 & $\begin{array}{l}\text { Curriculum needs supportive } \\
\text { teaching methods. }\end{array}$ & 0.80 & 4.21 & 1 & High \\
\hline 15 & $\begin{array}{l}\text { The curriculum lacks the thrill } \\
\text { element. }\end{array}$ & 0.77 & 3.73 & 2 & High \\
\hline 13 & $\begin{array}{l}\text { The objectives focus on } \\
\text { conservation and indoctrination } \\
\text { without being concerned with } \\
\text { applied and innovative aspects. }\end{array}$ & 0.75 & 3.71 & 3 & High \\
\hline 12 & $\begin{array}{l}\text { The curriculum contains concepts } \\
\text { and terminology above students' } \\
\text { level of awareness. }\end{array}$ & 0.96 & 3.51 & 4 & Average \\
\hline 11 & $\begin{array}{l}\text { The curriculum's relation to the } \\
\text { students 'needs and their working } \\
\text { life is weak }\end{array}$ & 0.83 & 3.31 & 5 & Average \\
\hline Total & \begin{tabular}{l} 
and \\
\hline
\end{tabular} & 0.10 & 3.06 & Average & \\
\hline
\end{tabular}

Table (7) shows that Paragraph No. (14) Which states, "Curriculum need supportive educational methods" came first with a high estimate, with an arithimtic average of (4.21) and a standard deviation of (0.80). This may be attributed to the fact that educational methods have a fundamental role in enriching education by adding special dimensions and effects and distinct programs, as they work to expand student experiences, and facilitate the construction of concepts and cross geographical and natural boundaries, and this role undoubtedly has been doubled nowadays due to the successive technological developments that It has made the environment surrounding the school a challenge to the teaching and learning methods of the school, because of this abundant environment of various means of communication that display educational content in exciting, bright and attractive methods. The primary goal of educational methods is to achieve cost effective measurable learning goals in terms of time, effort, and resources.

The methods of using computers in education have evolved, and attention has now focused on developing the methods used in teaching with the computer, or developing new methods through which the computer can contribute to achieving some of the objectives of the study subjects. The computer is an advanced means of transferring and distributing many study materials, because of its characteristics that make it a unique and effective educational method, as it provides a positive interaction feature between the user and the computer, it also provides individual care, and it is a motivational way and works to develop many educational trends.

Whereas, Paragraph No. (11) Which states, "The curriculum's relation to the students 'needs and their working life is weak, "came in the last rank with an average estimate, which is not satisfactory, nor weak, with an arithmetic average of (3.31) and a standard deviation of (0.83). This may be attributed perhaps to the need for curriculum to keep pace with the variables of the times and work to promote positive behavior among students, in addition to the importance of focusing on strengthening the national culture and away from the filling and indoctrination in the curriculum. And the necessity of reviewing the curriculim continuously and more comprehensively by specialists to adapt the students 'mental and psychological capabilities and needs, and that a mechanism is established through which these curriculum are reviewed periodically to meet the emerging needs and address problems that may arise in the field during the application, and the curriculum should take into account the individual differences between students and reviewing the educational content of some of the basic stage subjects and developing some curriculum, so that the student builds his knowledge on the basis of analytical 
thinking.broading the content of the curriculum with a large amount of information, and not keeping pace with the knowledge revolution and accelerated technology, has a negative impact on the desired quality of education. The process of development, modernization and review is an urgent necessity to keep pace with the changes of the times and to promote positive behavior among students, In light of globalization and modernity, where the student has become more able to deal with technology.

Results related to the axis of the reality of the education system in Jordanian schools with regards to exams: Table (8) presents them:

Table (8) arithmetic mean and standard deviations for the reality of the education system in Jordanian schools, as seen by both principals and teachers, for the fourth axis paragraphs: "The reality of the education system in Jordanian schools with regards to exams".

\begin{tabular}{|c|c|c|c|c|c|}
\hline No. & paragraphs & $\begin{array}{l}\text { standard } \\
\text { deviation }\end{array}$ & SMA & Arrangement & Appreciation \\
\hline 17 & $\begin{array}{l}\text { Some subjects need more } \\
\text { time to complete the exam. }\end{array}$ & 1.11 & 3.20 & 1 & Average \\
\hline 19 & $\begin{array}{l}\text { The phenomenon of } \\
\text { cheating in exams is } \\
\text { spreading. }\end{array}$ & 0.95 & 3.07 & 2 & Average \\
\hline 18 & $\begin{array}{l}\text { Students get distracted in } \\
\text { the exam as a result of their } \\
\text { anxiety. }\end{array}$ & 1.00 & 2.99 & 3 & Average \\
\hline 16 & $\begin{array}{l}\text { The test climate is } \\
\text { characterized by fear and } \\
\text { anxiety, as a result of some } \\
\text { procedures inside the halls. }\end{array}$ & 0.99 & 2.84 & 4 & Average \\
\hline 20 & $\begin{array}{l}\text { The exam suffers from } \\
\text { difficult questions and } \\
\text { changing its pattern. }\end{array}$ & 0.85 & 2.77 & 5 & Average \\
\hline \multicolumn{2}{|l|}{ Total } & 0.93 & 2.97 & \multicolumn{2}{|l|}{ Average } \\
\hline
\end{tabular}

It is clear from Table (8) that Paragraph No. (17), which states "Some subjects need more time to complete the exam" came first with an average estimate, with an arithimtic average of (3.20) and a standard deviation of (1.11). This may be attributed perhaps to the nature of the subject, the number and the nature of the exam questions.As sometimes, the lack of clarity of some questions leads to a large number of students 'inquiries and answers to them by teachers, and thus part of exam time is lost, and this requires more time to complete the exam.

Whereas, paragraph (20) which states "The exam suffers from difficult questions and changing its pattern" came in the last rank with an average estimate, with an arithimtic average of 2.77 and a standard deviation of (0.85). This may be due to the presence of questions that differ from the pattern of textbook questions that students are not used to answering in classroom and / or as homework, and thus suffer from its difficulty and changing its pattern.

Results related to the axis of the reality of the education system in Jordanian schools with regard to school administration: Table 9 shows them: 
Table (9) arithmetic mean and standard deviations for the reality of the education system in Jordanian schools, as seen by both principals and teachers, for the fifth axis paragraphs: "The reality of the education system in Jordanian schools in relation to school administration."

\begin{tabular}{|c|c|c|c|c|}
\hline No. & Paragraphs & $\begin{array}{l}\text { standard } \\
\text { deviation }\end{array}$ & SMA & Arrangement \\
\hline 25 & $\begin{array}{l}\text { School administration suffers from weak } \\
\text { cooperation with the local community. }\end{array}$ & 1.05 & 3.25 & 1 \\
\hline 24 & $\begin{array}{l}\text { School administration suffers from poor } \\
\text { communication with students. }\end{array}$ & 1. 23 & 2.89 & 2 \\
\hline 22 & $\begin{array}{l}\text { Schools suffer from the director's lack of } \\
\text { follow-up on the educational supervisor's } \\
\text { remarks. }\end{array}$ & 1.20 & 2.83 & 3 \\
\hline 23 & $\begin{array}{l}\text { Schools suffer from a lack of a suitable } \\
\text { educational environment for the student } \\
\text { and the teacher by the school } \\
\text { administration. }\end{array}$ & 1.11 & 2.65 & 4 \\
\hline 21 & $\begin{array}{l}\text { School administration suffers from the } \\
\text { negative impact of the economic } \\
\text { conditions of students 'families on the } \\
\text { learning of their children. }\end{array}$ & 1.08 & 2.43 & 5 \\
\hline \multicolumn{2}{|c|}{ Average } & 1.09 & 2.80 & \\
\hline
\end{tabular}

Table (9) shows that Paragraph No. (25) Which states "School administration suffers from weak cooperation with the local community" came first with an average estimate, with an arithmetic average of (3.25) and a standard deviation of (1.05). This may be perhaps attributed to parents or one of them being busy at work and the lack of their spare time, which may be reflected in their cooperation with the school administration regarding their children's school affairs, and also some parents may not be interested in educating their children , and are content only with enrolling them in school for a certain period of time to learn how to read and write, in order to leave school, teaching them and training them to practice a certain profession that accrues to them and their children with abundant money, according to their belief.

Whereas, Paragraph No. (21) Stipulates that "school administration suffers from the negative impact of the economic conditions of the students' families on the learning of their children"came in the last rank with an average estimate, and an arithmitic average of (2.43) and a standard deviation of (1.08). This may be attributed, perhaps, to the fact that the level of the family's culture, it's material and economic capabilities, and the degree of its ability to help their children have a significant impact on their academic achievement. The availability of a family environment that leads to achievement, which is based on positive interactions between the student, his parents and siblings, as well as care and positive family orientation for children are all conditions and factors that lead to achieving excellence. The child's affiliation with a certain socio-economic level also affects the relationships that arise between him and his colleagues, but rather the motivation for achievement. Also, the family's economic situation is directly related to the needs of learning and education, and therefore the shortage and material deficiency lead to a sense of deprivation and inferiority among the children and sometimes to theft and the generation of some hatred among society.

Second: The results of the second question and its discussion, which states the following: "Are there statistically significant differences in the level of $(\alpha \leq 0.05)$ in the reality of the education system in Jordanian schools as seen by both teachers and principals attributed to the nature of the type of job variable (teacher, principal)?

Arithmetic mean and standard deviations were calculated for the reality of the education system in Jordanian schools, as seen by the teachers and principals for each axis according to the variable (type of job), and table (10) shows the results of that. 
Table (10): The arithmetic mean and standard deviations for the reality of the education system in Jordanian schools were calculated, as seen by the teachers and principals for each axis according to the variable (job type)

\begin{tabular}{|c|c|c|c|c|c|c|c|}
\hline The axis & $\begin{array}{l}\text { Function } \\
\text { type } \\
\text { variable }\end{array}$ & SMA & $\begin{array}{l}\text { Standard } \\
\text { deviation }\end{array}$ & The axis & $\begin{array}{l}\text { Function } \\
\text { type } \\
\text { variable }\end{array}$ & SMA & $\begin{array}{l}\text { Standard } \\
\text { deviation }\end{array}$ \\
\hline \multirow{3}{*}{$\begin{array}{l}\text { 1) The reality of the } \\
\text { education system in } \\
\text { Jordanian schools } \\
\text { (with regards to } \\
\text { students. }\end{array}$} & Teacher & 3.81 & 0.74 & \multirow{3}{*}{$\begin{array}{l}\text { (4) The reality of the } \\
\text { education system in } \\
\text { Jordanian schools } \\
\text { (with regards to } \\
\text { exams). }\end{array}$} & Teacher & 3.05 & 0.95 \\
\hline & Principal & 3.43 & 0.50 & & Principal & 2.55 & 0.70 \\
\hline & Total & 3.75 & 0.72 & & total & 2.97 & 0.93 \\
\hline \multirow{3}{*}{$\begin{array}{l}\text { 2) The reality of the } \\
\text { education system in } \\
\text { Jordanian schools } \\
\text { (with regards to } \\
\text { teachers). }\end{array}$} & Teacher & 3.44 & 0.77 & \multirow{3}{*}{$\begin{array}{l}\text { 5) The reality of the } \\
\text { education system in } \\
\text { Jordanian schools } \\
\text { (with regards to } \\
\text { school administration) }\end{array}$} & Teacher & 2.86 & 1.13 \\
\hline & Princi pal & 3.39 & 0.77 & & Principal & 2.51 & 0.83 \\
\hline & Total & 3.43 & 0.77 & & total & 2.80 & 1.09 \\
\hline \multirow{3}{*}{$\begin{array}{l}\text { 3) The reality of the } \\
\text { education system in } \\
\text { Jordanian schools } \\
\text { (with regards to the } \\
\text { curriculum). }\end{array}$} & Teacher & 3.74 & 0.80 & \multirow{3}{*}{ total } & Teacher & 3.83 & 0.86 \\
\hline & Principal & 3.46 & 0.56 & & Principal & 3.07 & 0.65 \\
\hline & Total & 3.69 & 0.77 & & total & 3.33 & 0.84 \\
\hline
\end{tabular}

Table (10) shows an apparent difference in the values of mathematical averages for the reality of the education system in Jordanian schools, as seen by both teachers and principals for each axis according to the variable (job type), and to find out if these differences are statistically significant, a (t-test) was taken, table (11) shows the results of that.

Table (11) results of the t-test for the effect of (job type) on the reality of the education system in Jordanian schools, as seen by both teachers and principals for each axis according to the (job type) variable.

\begin{tabular}{|l|c|l|l|l|l|}
\hline Type of the job & SMA & Standard deviation & $\begin{array}{c}\text { Value } \\
\text { of } \mathrm{t}\end{array}$ & $\begin{array}{c}\text { Degree of } \\
\text { freedom }\end{array}$ & Significance level \\
\hline Teacher & 3.38 & 0.86 & 3.91 & 781 & 0.00 \\
\hline Principal & 3.07 & 0.65 & & \\
\hline
\end{tabular}

Table (11) shows that there are statistically significant differences at the level of significance $(\alpha \leq 0.05)$ in the reality of the education system in Jordanian schools, as seen by both teachers and principals for each axis according to the variable (type of job), and the differences were in favor of teachers. This may indicate more students' daily and direct relationship with teachers than that with principals, and therefore teachers notice these educational problems more closely, concretely and continuously more than the principal.

Third: The results of the third question and its discussion, which states the following: "What is the appropriate reengineering model for the education system to improve academic achievement of students in Jordanian schools from the viewpoint of teachers and principals?" In light of the results of the study, which showed the existence of a number of paragraphs with an estimate (high) that there are educational problems with a high degree, a reengineering model for the education system in Jordanian schools was developed, according to these paragraphs, as follows:

- Developing the model based on the relevant literature, which is included in the references, sources, articles and refereed studies?

- The literary background of the developed model.

- The general form of the developed model and its stages.

- Explain how to use the developed form in clear steps.

Below is a detailed explanation of the model, its importance and goals: 


\section{2. (Azhar Dagher model for reengineering the education system in Jordanian schools)}

The education system to improve the academic achievement of students in Jordanian schools depends on the type of job (teacher / school principal), and also on the prevailing organizational climate in the school in which they work, as well as the organizational culture in it. Accordingly, educational officials are supposed to pay attention to educational policies that improve the quality of education in schools, as well as to strategic plans that limit the occurrence of educational problems of various kinds.

* The education system and improving academic achievement:

The poor academic achievement may occur as a result of several reasons, some of which are self-related to the student, and other environmental related to the climate surrounding the student, especially (family and school climate), and there are social reasons for the low academic achievement of students, those reasons are related to having bad friends and ethical problems. There are psychological reasons related to the fear, anxiety to the exam, lack of self-confidence and neglect. There are also health reasons, audio, visual or mental obstaclesare related to the frequent absence of related to the inability to focus and perform school tasks in a correct way, and there are other factors no less important than the previous ones such as the quality of school administration performance and its role in shaping the effective school environment, and there is no doubt that the able teacher attracts The interest of her students towards realizing the mind, love of knowledge, and using the latest methods in education; this, in turn, is reflected to their academic achievement.

* Steps of reengineering the system to improve the academic achievement of students in schools:

The steps of reengineering the education system are represented in a group of main points, as follows:

1. Determining the problem clearly: defines the type of educational problems to be decided upon, identifying and distinguishing between them and knowing their symptoms and effects, and determining the degree of importance and size and the strategic factor in each problem,the "critical element" that must be changed or modified first of all, or the obstacle that if removed, problem is resolved, and determining the opportunity that results in improving or developing the work, and defining the problem is one of the guarantees necessary for the success of the decision about it. The first step is considered the appropriate solution way for each educational problem separately, and this contributes to improving the academic achievement of students in schools.

2. Collecting information on educational problems: This process requires determining the type of data needed on educational problems in schools and the appropriate sources of this data, and using and employing information. The process of identifying educational problems in schools with regard to students, teachers, school curriculum, exams, and school administration, and identifying possible alternatives that can reach it, and it must adopt the results and make the final decision to find solutions to educational problems to improve academic achievement of students in schools.

3. Suggesting a set of alternatives: After the process of collecting data on educational problems, analyzing their dimensions, knowing the reasons for their occurrence and examining the relationship between them, the educational decision maker moves to the stage of developing alternatives to solutions, or decisions that can be taken, and alternatives represent the primary solutions to educational problems that are proposed for the contents of the desired decision which is taken with the intention of comparison and analysis, until one of them is chosen, to become the last solution or decision, to find solutions to educational problems, to improve the academic achievement of students in schools.

4. Evaluating the alternatives to the solution: After the alternatives have been identified, the educational decision maker begins by comparing these alternatives in terms of their advantages and disadvantages and their contribution to achieving the goal and solving educational problems, and in terms of their suitability to the environmental conditions surrounding the school, and making comparisons of cost to benefit accounts, meaning a comparison between weights of the various alternatives to discuss the weaknesses and strengths of each alternative, the expected impact of each alternative if chosen and implemented, and compare the expected effects of each alternative and the future prospects for organizational goals, to find solutions to educational problems; to improve academic acheivement of students in schools.

5. Choosing the alternative that achieves the maximum return: This stage includes choosing the alternative, follow up and monitoring its implementationv, as a comparison is made between the available alternatives for the solution, in light of : the vision of the Ministry of Education, its mission, goals, legislative and legal dimension, cultural, social, political and economic dimension, and developments available globally as standards It contributes to the preference of one alternative over another, in addition to the advantages enjoyed by any solution offered, 
and its disadvantages, costs, results and multiples. There are a set of criteria and factors that influence the process of selecting an alternative.

Criteria and influencing elements are important criteria for selecting the alternative and its consistency with the Ministry of Education policy, plans, systems and philosophy, and they are compatible with the set of governing considerations determined by the benefit or the gains that can be achieved, the expected risk degree in choosing the alternative and the degree of its exploitation of available human and material resources, and taking into account all that surrounds The problem is socially, economically, politically, and culturally, and what is compatible with legislation and laws, within a moral context that binds the administrator to the standards of justice and the merits. and from the criteria and elements that influence the process of choosing the alternative is the harmony of the alternative chosen to be a decision with the decisions that preceded it, and the implications of this alternative, in addition to taking into consideration the circumstances of the targeted group (students) from the decision, inorder to find solutions to their educational problems to improve their academic achievement.

To ensure the validity of the form, it was judged by (6) arbitrators with educational experience, and the arbitrators agreed on the validity of the model developed, see Appendix No. (6).

Figure No. (1) Shows a model of Azhar Dagher for reengineering the education system in Jordanian schools.

\section{Recommendations:}

The results of the study concluded that there are statistically significant differences in the reality of the education system in Jordanian schools with regards to: (students, teachers, the curriculum, exams, and school administration), as seen by both principals and teachers, and therefore the study recommends based on the previous results with the necessity:

*Adopting the developed model that the study reached, and working to implement it .

*Carrying out practical studies to develop the education system, especially with regard to academic achievement among school students, with a methodology of reengineering administrative processes with the aim of achieving the best results with minimal effort, time and cost.

*Focusing on the basic stage in the educational process, from the point of view of providing the skills in a new and effective way, such as higher thinking skills and activating the role of educational supervision, to improve academic achievement of students in schools

*Working to create an atmosphere in the classroom so that love, cooperation and brotherhood prevail

*Follow-up students who suffer from difficulties in learning constantly, and transfer them to the room of learning resources available in the school.

*Using the student's colleagues to increase his attention and help him with the tasks required from him.

* Training of students with impaired attention in communication skills (speaking, listening).

* Providing hearing aids or visual aids, such as headphones and spectacles, whenever the student's lack of attention is an audio or visual problem

* Putting students with impaired attention in the front seats in the classroom

*Giving specific missions with clear instructions during a specific time period

* Reducing dispersed stimuli inside the classroom (regulating the classroom environment).

* The teacher using different teaching methods during class

* Using various modern and technical means 
Figure No. (1) Azhar Dagher model for reengineering the education system in Jordanian schools

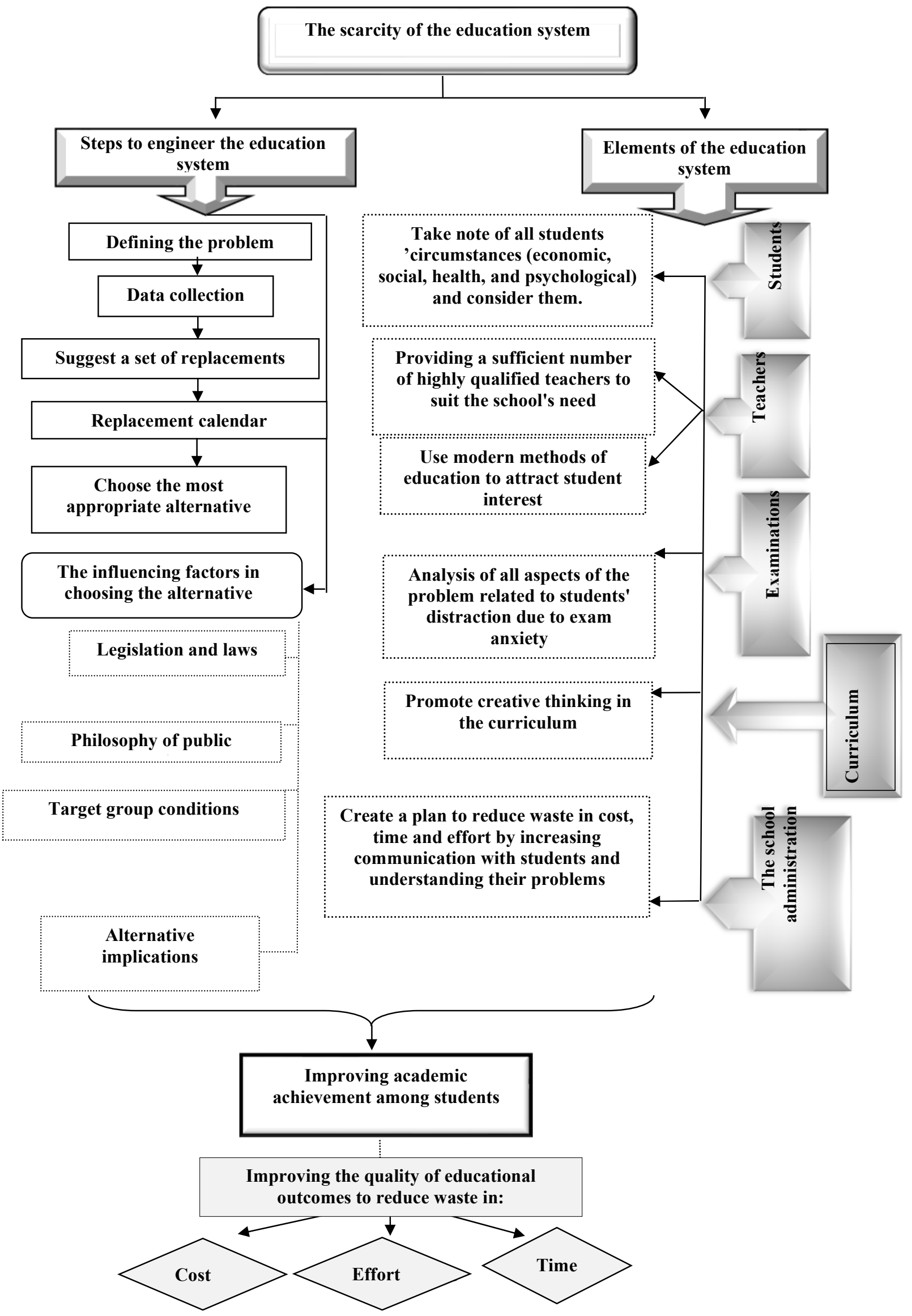




\section{References:}

Abdelrahman, E. (2017) Business Reengineering Obstacles and Future Aspirations to Overcome Them in the Ministry of Higher Education and Scientific Research of Jordan: a Prospectsive Study,Available from:

https://www.researchgate.net/publication/331959131_mwqat ttbyq_alhndrt_aladaryt_walttlat_almstqblyt ltjawz ha_fy_wzart_altlym_alaly_walbhth_allmy_alardnyt_drast_asttlayt [accessed Jun 03 2020].

Abdel Aziz, H. (2012) Pedagogical and Technological Incubations: A Proposed Visualization for Quality Control of Teaching in Higher Education Institutions, The Second Arab International Conference on Quality Assurance in Higher Education, from the website: (se.uofk.edu/multisites/UofK), [accessed Jun 05 2020].

Abdous, M., \& Wuhe. H (2008 b). A Framework For Process Reengineering In Higher Education: A Case Study Of Distance Learning Exam Scheduling And Distribution. The International Review of Research in Open and Distance $\quad$ Learning, $\quad 9(3): \quad 1492-3831 . \quad$ Retrieved from: (http://www.irrodl.org/Index.php/irrodl/article/view/535/1138), (22/3/2018)

Abdul Hafeez, A. (2009) Scientific reference to apply the curriculum of Hendra, sixth edition, Amman, Jordan: Wael House for Publishing and Distribution.

Ahmad, H., \& Rayes, S. (2013), The reasons for the low level of academic achievement of secondary school students from the viewpoint of teachers, and students, Surra Man Raa Magazine, College of Education, University of Samarra, 8 (28), 38-1.

Alam, A. (2012). Obstacles to students in learning and academic achievements at University of Peshawar. International Social and Education, 2(4), 738- 747.

Al-Azzawi, Kh. (2006) Management Decision Making Department, Amman, Jordan: Treasures of Knowledge House.

Al-Bawat, F. (2006) Reasons for students failing the General Secondary Education Certificate Exam in Jordan from the viewpoint of teachers, students, and parents, unpublished Master Thesis, Amman Arab University, Jordan.

Al-Dahyan, S. (1999) Sample Selection Guide, Cairo, Egypt: Egyptian Culture for Printing, Publishing and Distribution.

Al-Dajni, I. (2010) A suggested model for the re-engineering and computerization of administrative processes in institutions of higher education "case study", unpublished master's thesis, Islamic University, Gaza, Palestine.

Al-Hamali, R. (2008) Total Quality Standards in Arab Higher Education Institutions, Quality Assurance and Accreditation Council, Amman, Jordan: The General Secretariat of the Federation of Arab Universities.

Al-Kareemeen, H. (2006) Development of a model for educational decision engineering in the Ministry of Education at the level of senior management in Jordan, unpublished doctoral thesis, University of Jordan, Amman, Jordan.

Al-Khatib, A. (2001) University Administration: Recent Studies, Irbid, Jordan: Hamada Foundation for University Studies.

Al-Khatib, J. (2004) Teaching students with special needs at the regular school, Wael Publishing House: Amman, Jordan.

Al-Khawaja, M. (2008) Development of a model for the re-engineering of administrative processes at the Vocational Training Corporation in Jordan, unpublished doctoral thesis, University of Jordan, Amman, Jordan.

Al-Maayta, R. (2006) Developing an educational management strategy to increase the efficiency of workers in the middle management in the Jordanian Ministry of Education, in light of the human engineering methodology in the middle management in the Jordanian Ministry of Education, published doctoral thesis, Amman Arab University, Amman, Jordan.

Al-Rababah, H. (2015), Obstacles to Academic Achievement among High School Students (Tawjihi) From the Perspective of Successful and Unsuccessful Students and Their Parents, Jordan Journal of Educational Sciences, 11 (3), 301-285.

Al-Tamimi, I. (2014) Failure in Schools: Causes and Treatment, Al-Quds Open University Journal for Research and Studies, 34 (12), pp. 332-299.

Al-Tunaiji, S. (2008) A proposed model for developing the performance of workers in the Ministry of Higher Education and Scientific Research in the United Arab Emirates in the light of the methodology of re-engineering 
administrative processes, unpublished doctoral thesis, Amman Arab University for Graduate Studies, Amman, Jordan.

Al-Zaabalawi, M. (1998) Adolescent Education between Islam and PsychologyAl-Tarawneh, Suleiman, Khater, Ayman, and Tawiqat, Mashhour (2011) Degree of application of the terms of engineering process re-engineering in developing employees performance in the Fourth Amman Education Directorate, Al-Quds Open University Journal for Research and Studies, 1 (24): 267-311.

Ammar, H. (2000) Confronting Globalization in Education and Culture, Cairo, Egypt: Arab Library for Book.

Covington, M., \& Emlin, C. (2006) Fighting School Failure and Strategies for Ensuring Lasting Learning (Abdel Karim Gharib, translator). Morocco: Education World Publications.

Fliya, F., \& Al-Zaki, A. (2004). Glossary of terms for education, both verbally and in vocabulary, Egypt: Dar A1Wafaa for world of printing and publishing.

Gharib H. (2020) Organizational enablers of business process reengineering implementation. An empirical study on the service sector, International Journal of Productivity and Performance Management, Vol. 69 No. 2, 2020 pp. 321-343. Available from:

https://www.researchgate.net/publication/339068568 Organizational enablers of business process reengineeri ng implementation An empirical study on the service sector [accessed Jun 03 2020].

Hussein, S. (2006) School Administration and Distinguished Descendants, Amman, Jordan: Dar Al-Fikr.

Hussein, A. (2007) The Reengineering Revolution: A New Entry to the Education System, Alexandria, Egypt: The New University House.

Ismail, A., Gideon, P., \& Ghamrawi, N. (2009) Paper entitled "Developing and updating higher education plans and programs to keep pace with the needs of society", Twelfth Congress of Ministers Responsible for Higher Education and Scientific Research in the Arab World: "Aligning Higher Education Outcomes with the Needs of Society In the Arab World, "Arab Organization for Education, Culture and Science, Beirut, Lebanon, (10/ December/2009).

Khashman, A. (2019) The Effect of Business Process Re-Engineering on Organizational Performance: The Mediating Role of Information and Communications Technology, International Journal of Business and Management 14(9).pp.(132-149).

Khatiba, M., \& Al-Saud, R. (2009) The factors that contribute to the failure of students in the General Secondary Certificate Exam in the Governorate of Irbid from the point of view of supervisors, managers, teachers, and students, Mutah for Research and Studies, Humanities and Social Sciences Series, 24 (6), .50-1

Khalil, A. (2008) The role of engineering process in supporting cost reduction decisions under the philosophy of management of change, the eighth annual international scientific conference titled: Management of Change and the Knowledge Society, Al Zaytoonah University, Amman, Jordan.

Hummer, M., \& Stephen, S. (2000) The Reengineering Revolution (Your Guide to the Reengineering Management Processes revolution) Riyadh: Prospects for Creativity and Publication. (Translated by Hussein Al-Falahi), the original book was published in (1993).

Jordanian Ministry of Education Online website (www.moe.gov.jo/en/reports), Statistics for the year (2018/2019). Morsi, M. (1998) Education Planning and Economics, Cairo, Egypt: The World of Books.

National Quality Assurance and Accreditation (2004) The Quality Assurance and Accreditation Handbook: National Quality Assurance and Accreditation, from: (www.ncqa.org), [accessed Jun 242020 ].

Obaidat, S., \& Al-Rashdan, A. (1993) Education in Jordan from (1993-1921), Amman, Jordan.

Oubedda, L., Erraha, B., \& Khalfaoui, M. (2012) Data Intelligent Analysis for Decision-Making at Universities, Published by Canadian Center of Science and Education. Computer and Information Science, 4(5): 61-67, ISSN: 1913-8989.

Peter, D., \& Ruth, D. (2013). Influence of family factor on senior secondary school students achievement in government in Edo North Senatorial District. Unique Journal of Education Research, 1 (4), 44- 53 .

Sultan, F. (2001) Re-engineering Business Systems (BPR): Theory and Practice. The Second Arab Conference, Creative Leadership in Facing the Contemporary Challenges of Arab Management, Cairo, Egypt. 
Author's biography : - The author was born in occupied Palestine in 31/10/1979.

She has a PhD in Educational Administration from University of Jordan ,Amman - Jordan in 2014 with an excellent degree.

Current workplace: Jordanian Ministry of Education

Authoring many educational books published in Jordan and outside Jordan

Publishing (7) educational researches in peer-reviewed scientific journals within Jordan and the Arab world.

Publishing (7) other research papers in scientific and international conferences.

Winning second place in the competition for the best research presented in the (Fifth International Conference for the Humanities) at the Meridian Hotel - Amman from 18-20 / 4/2016, which was organized by the London Center for Research and Consulting in cooperation with the Arab Thought Forum entitled "Contemporary trends in educational institutions" ... reform and development, "which discussed 54 scientific papers of 60 researchers from 12 Arab countries. (Winning a shield and a certificate of excellence), in a published research paper, entitled: "The Quality of Jordanian Higher Education Outputs: A Study from the Viewpoint of Academic Leadership in Jordanian Universities." 